\title{
Revelation as a discourse of language through speech act theory
}

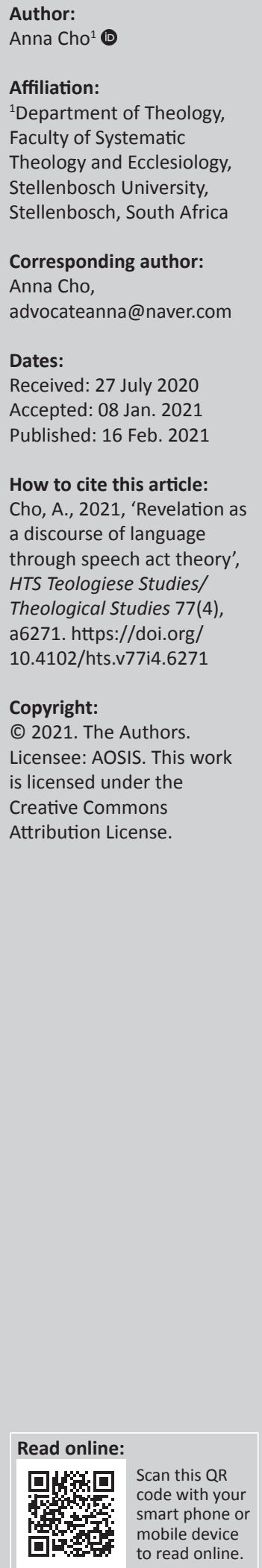

Systematic theology regards revelation as a divine discourse between God and us. However, it seems that it does not fully explain how God's divine discourse transforms our life and what implications it has. Therefore, this article suggests investigating 'revelation as a discourse of language' in the light of speech act theory (SAT). If we illuminate revelation as a discourse of language as a SAT, the following three hermeneutical contributions to revelation are expected: firstly, revelation is a 'communicative act' between God and believer as a 'discourse of language' of God; secondly, it shows how the language of revelation bridges the gap between 'divine language' and 'human language' in terms of revelation as a discourse of language, and thirdly, it confirms how God's Word (revelation) is real in the lives of believers.

Contribution: While this article engages the traditional theological notion of revelation as a discourse of language between God and humans, it argues that reconsidering this notion in the light of speech act theory. It can explain God's language discourse transforms the lives of believers and the Word (revelation) is fulfilled in their lives.

Keywords: Revelation; discourse of language; communicative act; speech act theory; realization of revelation.

\section{Discourse about God}

Theology is 'discourse about God' (McGrath 2012:1). In this perspective, it can be considered that the Bible is a discourse about God. In most cases, God reveals God's self through God's Word (the Bible) and God's actions. In this regard, God's revelation can be seen as the 'SpeechActs of God' revealed in the Bible. ${ }^{1}$ For example, in Exodus 3, God's self-disclosure of 'I am who I am' is God's utterance (saying), and it presents what God is (being) and what God does (doing). God, the Creator and sovereign governs and rules God's people through God's Word with God's action. Also, it includes what God has done for his people (past-present) and what God will do in the future, namely, God reveals God's self in 'language' and acts through 'language'.

The literal meaning of revelation ${ }^{2}$ is that God who has been hidden has been revealed. When revelation is the manifestation of God, it can be said to be the coming of God to believers through the Word. In this sense, God's disclosure implies a relational meaning as a language itself in terms of divine discourse. According to Migliore (2004:20, 21), revelation is fundamentally a knowledge of God and us, and the revelation of God is an event of transformation that overthrows, overwhelms and becomes a reality in our lives. From this viewpoint, revelation is not simply about the hidden information, enlightenment or knowing of God in the propositional statements of the Bible. Rather, it is a 'dynamic practical faith event' of the Word transcending texts in the ordinary life of believers. It invites the people of God into the presence of God and God's salvation ministry in the communicative act between a mutually personal relationship. Revelation, therefore, as Basil Mitchell (1980:105) pointed

1.God's acts in history are not limited to linguistic acts. However, the discussion of revelation in this article limits the scope of the study by looking only at the speech-acts of God as a linguistic approach.

2.Avery Dulles identifies five models of revelation in his famous book Models of Revelation. The first one is revelation as authoritative doctrines. It means authoritative doctrines or revealed propositions, but the revelation of God cannot be limited to a set of authoritative propositions. Second is revelation as historical events. This equates revelation with certain historical events, which focus on God's propositions. Second is revelation as historical events. This equates revelation with certain historical events, which focus on God's
actions in history, but it has limitations that cannot explain the relationship between the actions of God and the Christian's response to actions in history, but it has limitations that cannot explain the relationship between the actions of God and the Christian's response to
them. Third is revelation as a special inner experience. It is essentially an inner feeling of fellowship with God, but this is subjective and them. Third is revelation as a special inner experience. It is essentially an inner feeling of fellowship with God, but this is subjective and can be tilted to an extremely personal perspective and experience. Fourth is revelation as dialectical presence. This model explains that
although God's Word is mediated by human language, it cannot be identified with the human word itself. This, in turn, has the weakness although God's Word is mediated by human language, it cannot be identified with the human word itself. This, in turn, has the weakness
of not providing an understandable connection between God and humans. Fifth is revelation as transformative action. It is seen as a breakthrough in human consciousness that expresses itself in creative imagination and moral action. However, it has the weakness of disregarding biblical testimony and tradition. Consequently, he considers all five models unsatisfactory. 
out, communicative act as discourse of language. ${ }^{3}$ In spite of these facts, the revelation as a discourse of language has not been dealt with enough in systematic theology. If revelation is God's discourse, it involves a 'mutual personal communication' between the God revealed in the Bible and the believer in response to God's speech act. The interdependent communication of revelation in this sense is not merely for mutual understanding. Rather, God asks believers to participate in God's speech act. When believers respond appropriately to God's Word, God's language discourse transforms the lives of believers and the Word (revelation) is fulfilled in their lives. Divine discourse becomes a reality in the lives of believers, which entails proper acts or speech acts between God and believers. Therefore, this article suggests that revelation should be examined through speech act theory (SAT) in order to understand it as the discourse of God. If we illuminate revelation as a discourse of language as a SAT, the following three hermeneutical contributions to revelation are expected: firstly, revelation is a 'communicative act' between God and believer as 'discourse of language' of God; secondly, it shows how the language of revelation bridges the gap between 'divine language' and 'human language' in terms of revelation as discourse of language; and thirdly, it confirms how God's Word (revelation) is real in the lives of believers. Therefore, this article examines revelation as a discourse of language through SAT.

\section{Revelation as discourse of language in terms of speech act theory \\ The basic concept of speech act theory and the revelation of mutually personal communication act}

It is not easy to define $\mathrm{SAT}^{4}$ in one word. This is because, in a broad sense, SAT studies the use of language. It examines how language is used in human society, how language affects it and how the meaning of language is studied and utilised extensively. To be specific, SAT studies the 'relationship' between 'language (text/author)' and 'language users (reader/interpreter)', and 'speaker' and 'hearer', and explores its effects and consequences. The purpose of this discussion is to grasp the intention, meaning and purpose of the speaker (text), revealed or hidden, and to pay attention to how the speaker and the hearer communicate with each other. Therefore, to examine the revelation of God in the Bible through SAT is to look at the act of communication through 'interaction (relationship)' between the 'text' and the 'reader'. What is important here is that to know God's revelation in the Bible in terms of the interaction is not simply to understand the content of revelation or the lessons that

3.Dulles's (1992:62-67) second model of revelation as historical events argues that revelation is not equated with the biblical text itself but is located in historical events in the Bible. It refers to God's action revealed in God's revelation history. interpretation of the Bible's testimony of God's action and the response of believers.

4.In this article, the overall understanding and introduction of SAT is omitted in order to focus on its application to revelation. Therefore, this article attempts to satisfy only the basic concept of SAT necessary for the discussion of revelation as a language discourse and some key features. revelation gives us. Rather, God's revelation is about what intention (meaning) God reveals to us and how we should respond to God's revelation. That is, the purpose of God's revelation includes not only the content of the revelation but also the practical life of the Word as intended by God in the believer's life. It means that believers participate in the revelation of God in ordinary life. In other words, revelation must become a reality as God living in the lives of believers. Knowing the revelation of God through the Bible is not simply a knowledge of proposition but of God's intent through 'mutual personal relational communication' between God (text) and the believer (reader) and the actual faith events that respond to the Word (revelation). Thus, SAT shows who God is as revelatory communication of mutual personalities and leads to theological and religious implications.

Simply speaking, SAT is a theory of 'word-action'. Speaking in SAT means acting; meaning is action. The issue is about what one is doing when saying something and what effect the act of saying something has on the hearer. This is possible because of the performance characteristics of the language. John Austin, the founder of SAT, regards 'constative utterances' as 'performative utterances', claiming that most languages have performance characteristics. Austin (1975:94-109) divided the performative utterances into the locutionary, the illocutionary and the perlocutionary acts: the locutionary act refers propositional meaning, the illocutionary act indicates speaker's intent and the perlocutionary act is the result of the illocutionary act.

For example, suppose that A and B went to the mart to buy something, and in front of the counter, A discovered that he did not bring his wallet. B, who found out about this, says to A, 'I have a wallet'. B's utterance refers to 'constative utterances' indicating the fact that he has a wallet (informative fact: locutionary act) and at the same time 'performative utterances' indicating that he would like to pay for A (act), and strictly speaking, execution is performed. In other words, the statement 'I have a wallet' is a constative utterance in a superficial sense (proposition) but is a performative utterance in a practical sense (reality). To put it precisely, 'I have a wallet' is to carry out a conversation involving the meaning of 'promise' that B will pay money instead of A as an illocutionary act. In other words, the statement 'I have a wallet' means 'I will pay for you'. Stated differently, B's utterance, 'I have a wallet' is an illocutionary act of 'promise'. By speaking, B acts. Also, B completely transforms A's reality of not being able to pay into a reality of being able to pay. This shows that the effectiveness of the speaker's utterance is realised through the illocutionary act as a 'promise'. Thus, the illocutionary act as promise is a clear demonstration of interrelated communication.

This example helps us to understand how God's revelation (Word) in the Bible communicates with believers in the performance aspect of language. In addition, God's people should also engage in relational communication in response 
to the Word, which will be made real to them. To summarise, through this communicative act, God reveals God's self and God communicates with believers. God's revelation (Word) is fulfilled in the lives of believers through communicative acts that require believers in God to trust God's revelation (covenant) and live in response to the covenant.

\section{Divine language and human language: Is God knowable?}

The paradoxical notion of revelation that God is revealed and hidden at the same time has the premise that we cannot know God. In the traditional Christian view, the literal meaning of revelation implies that the knowledge we have about God is that God is partially known or cannot be fully understood. However, as discussed earlier, if revelation is a relational communicative act, we must assume that we know God. Because when we know God or God's intentions, we can have right or proper communication with God. If so, we must ask here, is God someone who is really unknowable? Is it not a plausible argument that the revelation is a language discourse between God and believers? In addition, the Word is divine. Can we interpret this divine language as human language?

To answer these questions, we need to break away from the concept of traditional revelation for a moment. If so, is not our discussion going to be meaningless? The answer is ' $\mathrm{No}^{\prime}$. However, our discussion is trying to say that there is a different approach to revelation by using SAT. To tell the conclusion, rather than paying attention to what we know about God in the Bible as propositional knowledge, we must grasp God's intent in God's speech act. We cannot know everything about God, but we can understand God's 'intentions' through God's discourse of language in the Bible (revelation). As Migliore (2004:22) pointed out, the Bible shows that believers do not say, 'what must I know?' but 'who must I be and what must I do to be saved?' (see Mk 10:17; Jn 3:3). Stated differently, the revelation of God in the Bible reveals God's intentions to us and shows us how we should live as God's people on earth, that is, communicating with God as revealed by the Word and believers is not about a full knowledge of God, but about understanding the intention of the Word with action following the revelation. For example, let's look at God's revelation of 'I am holy, so be holy' (Lv 11:45). This presents God's identity that God is holy as divinity of God at the locutionary level. The purpose of this revelation of God is not just to show that God is holy. Rather, the intention is that you shall be holy (illocutionary act) because God is holy (locutionary act). Therefore, God's revelation is not merely self-disclosing but demands that we live according to it. In other words, the revelation of God includes the determination and life of faith in which believers respond correctly to God's revelation (perlocutionary act).

Speech act theory helps to grasp the intentions of the speaker (author/text) through the illocutionary act. It analyses the communication between speaker and hearer in ordinary life. In SAT, the intention of the speaker is what the speaker is trying to say, and the utterance of the speaker comes to the hearer by the performative language effects. In other words, the speaker's utterance becomes a reality through communicating with the hearer and by proper behaviour according to speaker's utterance. In SAT, the illocutionary act contains both the content of the utterance of the speaker (locutionary act) ( $p$ ) and the illocutionary force $(\mathrm{F})$ that is to do something. They cannot be separated from each other. This represents the performance of the language, that is, the language becomes a reality as the contents of the utterance accompany the action.

For example, God's revelation of 'I am holy, so be holy' (Lv 11:45) can be interpreted as 'God is holy (p), and you shall be holy $(\mathrm{F})^{\prime}$ '. It can be represented as 'God is Lord, my Father $\mathrm{F}(p)$ ' or 'I am a Christian $\mathrm{F}(p)$ '. This shows divine language as self-discourse at the locutionary level and human language as the experience of God at the illocutionary level. Thus, it describes both divine language and human language, which are carried out at the same time without being separated because of the performance characteristics of the language.

The Bible as God's revelation is not a cryptic statement of mystical language. The nature of divine language is not a collection of secret symbols, but the performance of language. As God said, 'let there be light' and there was light, God's Word has the power to carry out the Word, and the Word has the power to change reality. This is because of the performative character of language. Speech act theory focuses on the performative characteristics of language. It explores the proper conditions for the speech acts that we perform in everyday life. God spoke in human language when God spoke to humans, and in human language, God also spoke at the human level, sometimes in a parable, considering situations, circumstances, culture and background. The language of the Bible is a combination of human daily life and divine language. To be precise, through the ordinary language of humans, the divine nature is revealed. The characteristic of divine language lies in the 'performance of language'. With the clear intent of God's utterance, the language is performed to the hearer. The Word affects the life of a believer who is in harmony with God's actions. Therefore, the Word of God becomes a reality in the life of the believer.

\section{The realisation of God's language discourse and Christian life}

We have confirmed that revelation is a discourse of language between God and believers. If so, the revelation of God as a discourse of language should become a reality in the lives of believers. Then, how does revelation become a reality?

The revelation of God as a manifestation is connected with faith because the revelation (Word) of God reflects the life of believers, so that a believer's life is different from his previous life, and the person feels differently and lives differently. This work of revelation enables us to recreate and reinterpret the whole reality of our lives in revelation. In other words, God's revelation requires our personal response, 
appropriation and practice of the Word through God's verbal act. The coming of God's revelation is not a one-sided approach of God but an act of mutual personal communication based on a personal relationship, requiring the personal response and participation of God and human. Thus, the purpose of revelation is to live a transformed life in which believers trust in God and act rightly, by revealing God's self through language (Word). Therefore, revelation as a discourse of language makes us experience the living God in everyday life in terms of the revelation of a mutually personal communication act between God and us.

Here we should be able to question how the revelation transforms the lives of believers, how we can explain God's divine work (the Holy Spirit) in the believers and the reality of revelation as God's discourse of language through SAT.

The revelation of God in the Bible is manifested in the promises and demands of the faithfulness of God's revelation in terms of the communicative act (Thiemann 1985). Stated differently, it always has the performance of the language, and the fact that the language has a performance means that 'the intention of the language' to speak is clear. In SAT, the illocutionary act refers to the speaker's intention by the illocutionary force. It brings out 'reality' in real-life situations by execution of intention. It is linked to the direction of fit. The speaker's illocutionary act is to be a reality by asking the hearer to perform action in the relationship between word and world, namely, the speaker's intention decides the 'direction'.

Searle (1979:10-20) argued that directives and commissives have 'the world-to-word direction of fit', that is to say, they are successful only if the world is changed in order to fit the utterance. God's communicative revelation has an intention. In most cases, it is shown as a promise, no matter what kind of illocutionary act (advices, counsels, warnings, requests) is performed according to 'God's intention'. This is because, in terms of intention and meaning, whether it is a warning, a reproof or a question, it carries out the illocutionary act as the meaning of promise. For example, the professor tells the student, 'I will give $\mathrm{A}+$, if $100 \%$ attendance' is the language of a promise. However, this can be expressed as the language of warning 'I will not give A+, if you do not attend 100\%'. Although the form of utterance is different and the contents of the utterance are the opposite, the utterance of the professor has a linguistic aspect of promise that 'I will give $\mathrm{A}+$, if $100 \%$ attendance' considering the intentional meaning of utterance. Why? The professor's intention is to give A+ to the students who have $100 \%$ attendance, not to warn them of not giving $\mathrm{A}+$. There is something important here. There are conditions that a professor's utterance must fulfill in order to be real in students' lives. A professor must keep his promises 'faithfully' according to his own utterances, and when students 'believe' $100 \%$ of the professor's utterances, if they 'participate $100 \%$ of the class', the professor's words become real in their lives by getting $\mathrm{A}+$. In short, the professor's utterance entails a 'world-to-word', which should transform the world by the future course of action of the speaker.
Considering the given example through SAT, the process by which speech acts are actualised can be explained through the illocutionary force's direction of fit and Evans' theory of self-involving activity. The illocutionary force of revelation $\mathrm{F}(p)$ has a direction of fit that represents the purpose and intent of revelation. In other words, the revelation $\mathrm{F}(p)$, which is spoken as a language, encounters a direction of matching between word and world. This explains how revelation as a discourse of language that takes its influence from life out of the 'Word' becomes reality in everyday life in relation to communication between God and believer. Revelation as a language discourse does not just stay in the text, but it does what it says. This means that God has responsibilities and duties in 'speech-acts (language events)' that reveal God's self to believers in order to make the content of the revelation $(p)$ to be a real $\mathrm{F}(p)$. In other words, God's revelation refers to God's self-involving activity in language events. Thus, revelation is the coming of God to communicate with us, the gift of salvation, invitation and grace. For example, God's revelation of 'I am holy, so be holy' (Lv 11:45) can be seen as 'God is holy, and God makes you holy $\mathrm{F}(p)$ ' by God's selfinvolving activity (direction of fit). Therefore, as a selfinvolving activity of God in revelation in language events, language transforms the world into reality. God's selfinvolving activity in revelation makes it possible for the covenant communion with the believer to become a real event. At the same time, it allows the believer to participate in the discourse of language (revelation), and the effect is accompanied by the perlocutionary act in the believer.

\section{Conclusion}

We have examined 'revelation as a discourse of language' through the insight of SAT. The revelation as a discourse of language means that God's revelation in the Bible is not a series of knowledge or knowing of God, a secret doctrine, but a speech act of God, a language event in which God's wordactions become reality in the lives of believers. Thus, revelation as a discourse of language is a 'mutual personal communication act'. The act of interpersonal communication of revelation is not merely aimed at conveying something about God's manifestation. Rather, it invites believers into the events of God's revelation in a personal relationship between God and believers. This revelation as a language discourse is about God's living manifestation, transforming the lives of believers and enabling God's revelation (Word) to be fulfilled in the lives of believers. Therefore, the revelation as God's speech act becomes a reality in the lives of believers, which entails appropriate acts of communication between God and believers.

This understanding of revelation as a discourse of language reveals God's revelation in the dynamic spiritual work of living and speculative notions of God's revelation in the Bible, facing and experiencing it. Revelation is not an indication of the simple manifestation of God but an event and reality of faith. Therefore, the revelation of God is a discourse of language that accompanies God's divine action and urges believers to live according to the revelation content. 


\section{Acknowledgements}

Written in honour of my spiritual mother, Heide, and father, Ulli Lehmann.

\section{Competing interests}

The author declares that she has no financial or personal relationships that may have inappropriately influenced her in writing this research article.

\section{Author's contribution}

I declare that I am the sole author of this research article.

\section{Ethical considerations}

This article followed all ethical standards for a research without direct contact with human or animal subjects.

\section{Funding information}

This research received no specific grant from any funding agency in the public, commercial or not-for-profit sectors.

\section{Data availability}

Data sharing is not applicable to this article as no new data were created or analysed in this study.

\section{Disclaimer}

The views and opinions expressed in this article are those of the author and do not necessarily reflect the official policy or position of any affiliated agency of the author.

\section{References}

Austin, J.L., 1975, How to do things with words, Harvard University Press, Cambridge.

Dulles, A., 1992, Models of revelation, Orbis, Maryknoll, New York, NY.

McGrath, E.A., 2012, Historical theology: An introduction to the history of Christian thought, Blackwell Publishing, Malden, MA.

Migliore, D.L., 2004, Faith seeking understanding: An introduction to Christian Theology, Eerdmans, Grand Rapids, MI.

Mitchell, B., 1980, 'Does Christianity need a revelation?', Theology 83(1), 103-114. https://doi.org/10.1177/0040571X8008300205

Searle, J.R., 1979, Expression and meaning: Studies in the theory of speech act, Cambridge University Press, Cambridge.

Thiemann, R.F., 1985, Revelation and Theology: The Gospel as narrated promise, University of Notre Dame Press, Notre Dame, IN. 